\title{
“ LEGAL RESPONSIBILITY OF THE COMPANY PROVIDING ONLINE TRANSPORTATION AND DRIVING SERVICES PROVIDERS ON CONSUMERS"
}

\author{
Frans Kurniawan ${ }^{1 *}$, Abdul Gani Abdullah ${ }^{2}$, Amad Sudiro ${ }^{3}$ \\ ${ }^{1}$ Doctoral Program in Law, Faculty of Law, Tarumanagara University, Jakarta, Indonesia ${ }^{2}$ Professor at Faculty of Law, \\ Tarumanagara University, Jakarta, Indonesia ${ }^{3}$ Professor at Faculty of Law, Tarumanagara University, Jakarta, Indonesia \\ *email: fransk848@gmail.com
}

\begin{abstract}
:
The legal relationship between application companies, drivers, and consumers often create confusion. The consumer's contractual relationship is with the application company. Furthermore, the application company has a partnership contract with the driver. Drivers are the ones who directly interact with consumers to fulfill the services to consumers. This research aims to find the responsibility of the online transportation provider and driver to consumers. This research is normative legal research. It uses secondary data. The study found thatthe application company should be responsible for consumer losses in the event of a loss because it has a contractual relationship with the consumers.
\end{abstract}

Keywords:

Consumer Protection, Civil Law, Online Transportation

Article Received: 18 October 2020, Revised: 3 November 2020, Accepted: 24 December 2020

\section{INTRODUCTION}

At the beginning of online transportation service providers in Indonesia, there was no exact legal status in conducting their business. Until finally the Minister of Transportation of the Republic of Indonesia, as the official in charge of handling various matters concerning transportation in Indonesia, issued a Regulation of the Minister of Transportation of the Republic of Indonesia Number PM 32 of 2016 concerning the Implementation of Insider Transport in Public Motor Vehicles Not in Route (hereinafter referred to as Permenhub No PM 32 of 2016 ). Permenhub No.PM 32 of 2016 has become the first legal instrument governing the existence of online transportation. Then Permenhub No PM 32 of 2016 was changed to Regulation of the Minister of Transportation of the Republic of Indonesia Number PM 26 of 2017 concerning the Implementation of Public Vehicle Insider Transport Not in Route (hereinafter referred to as Permenhub No.PM 26 of 2017). Still, Permenhub No PM 26 of 2017 was submitted an application material test to the Supreme Court of the Republic of Indonesia (MA) by six online transportation drivers.
As a judiciary, the Supreme Court has the authority to conduct a judicial review of statutory regulations under laws that contradict laws. The Supreme Court decision on the judicial review of the Minister of Transportation Decree No.PM 26 of 2017 is to grant the applicant several articles that are considered contrary to Law No. 20 of 2008 concerning Micro, Small, and Medium Enterprises (hereinafter referred to as UUUMKM) UULLAJ. There are 14 (fourteen) points in Permenhub No. PM 26 of 2017, which are revoked by the Supreme Court. The Supreme Court Decree result was immediately responded to by the Ministry of Transportation with the issuance of the Minister of Transportation Regulation of the Republic of Indonesia No.PM 108 of 2017 concerning the Implementation of Transportation of People with Public Motor Vehicles Not in Route (hereinafter referred to as Permenhub No PM 108 of 2017) government efforts to ensure certainty and protection law for consumers and businesses.

Provisions regarding consumer protection in Indonesia have been implemented with the birth of Law No. 8 of 1999 concerning Consumer Protection (hereinafter referred to as Consumer 
Protection Law). Consumer Protection Law's existence is a government effort to guarantee that every community who acts as a consumer has the right to obtain their rights properly. Because in carrying out business activities, every company certainly desires to get maximum profit, so it does not give consumers the correct rights. The government's role as the state organizer is significant to ensure that Indonesia's economic activities can improve the community's welfare. In connection with producing and trading goods and or services, consumers need to be protected because protecting consumers means ensuring the continuity of national development, guaranteeing development financing sources, and improving the efficiency of people's living costs.

\section{THEORETICAL CONCEPT}

\subsection{Definition of responsibility}

The term responsibility, in English, can have two meanings, namely responsibility, and liability. The term responsibility has the meaning of responsibility for carrying out a task or an object or person. In contrast, the term liability indicates the obligation to compensate for a loss suffered by another party. It may be due to an action, breach of contract, action against the law. It could also mean action against something that belongs to or is under the control of another party.

According to the law, responsibility results from the consequences of a person's freedom of conduct related to ethics or morals in carrying out an act (Hamzah, 2005). According to Mustafa (2016), responsibility means burden borne by one or more for actions carried out or decisions that have been issued.Jimly Asshiddiqie and Ali Safa'at (2006), in their book Hans Kelsen's Theory of Law, stated that the concept of legal obligation is related to legal liability. A person said to be legally responsible for a particular act is that he can be subject to a sanction in the case of an opposing act. In the case of sanctions imposed is because of his actions make the person must be responsible.

According to civil law, primary liability is divided into two types, namely error, and risk. It is known as a liability based on errors (liability without based on fault) and liability without known errors (liability without fault), which is known as risk responsibility or absolute responsibility (strict liability). The basic principle of accountability based on mistakes implies that a person must be held responsible because he made a mistake. After all, it harms others. Instead, the principle of risk responsibility is that the plaintiff's consumers are no longer required, but the defendant's producers are directly responsible for their business risks Triwulan and Febrian, 2010).

\subsection{Classification of Obligations.}

Rahardjo (214) classifies obligations into a. Absolute and relative obligations.

Austin argues that absolute obligations are those that do not have pairs of rights, such as selfdirected obligations demanded by society in general, which are only shown to the powers that govern them (Widjaja, 2071a). The relative obligation is that which involves rights, on the other hand.

b. Obligations and civil rights.

Public obligations are those that correlate with public rights, such as obligations to fulfill criminal law. Civil liabilities relateto civil rights, such as obligations arising from agreements (Widjaja, 2017b).

c. Positive and negative obligations.

Positive obligations require positive actions, such as the seller's obligation to deliver the goods to the buyer. Negative obligations are those that need a party not to do something, such as a person's obligation not to do something that disturbs the property of a neighbor.

d. Universal, general and special obligations. 
Universal obligations are aimed at all citizens, as arising from the law. General obligations are aimed at a particular group of people, such as strangers, parents (father, mother). Special obligations are those arising from specific fields of law, such as obligations in treaty law.

e. Primary obligations, which are sanctions in nature.

Primary obligations do not arise from actions against the law, such as one's obligation not to defame another person, in this case not arising from violations of other previous obligations. Obligations that impose sanctions are those that arise solely from acts against the law, such as the defendant's obligation to pay the lawsuit of another party who has won the case.

\subsection{Theory of Responsibility.}

According to Abdulkadir Muhammad (2010), the theory of responsibility in unlawful acts (tort liability) is divided into several theories, namely:

a. The responsibility resulting from unlawful acts that are carried out intentionally (intentional tort liability), the defendant must have committed such acts to harm the plaintiff or know that what the defendant will do will result in losses.

b. Liability due to unlawful acts committed due to negligence (negligence tort liability) is based on the concept of error (the concept of fault) relating to morals and laws that have been intermingled.

c. Absolute responsibility resulting from actions that violate the law without questioning errors (strict liability) is based on both intentionally or unintentionally. It means that even though it is not his fault, he is still responsible for losses arising from his actions.

\subsection{Principle of Responsibility}

According to the law, responsibility results from the consequences of a person's freedom about his actions relating to ethics or morals in carrying out an act. According to the Quarterly Point, liability must have a basis, that is, a matter that causes the emergence of a legal right for someone to kneel another person at the same time in the form of something that gives birth to someone else's legal obligation to provide responsibility (Triwulan and Febrian, 2010). In general, the principle of responsibility in law can be distinguished as follows (Kristiyanti, 2009):

\section{a.Liability based on fault}

The principle of responsibility states that a person can only be held legally liable if there is an element of wrongdoing. The injured party is charged to prove that the person has made a mistake. This principle is a reasonably general principle applicable in civil law,particularly Articles 1365, 1366, and 1367 Civil Code. In general, this principle of responsibility is acceptable because it is fair for the person who did wrong to compensate the victim. In other words, it's not fair if an innocent person has to pay for the damage suffered by someone else (Rahardjo, 2014).

The matter that needs to be explained in this principle is the definition of wrongdoers, which in the legal doctrine is known as the principle of vicarious liability and corporate liability (Kelsen (translation), 2006). Vicarious liability implies that the employer is responsible for losing other parties caused by people or employees under his supervision. Corporate liability has the same meaning as vicarious liability. According to this doctrine, the institution that houses a group of workers is responsible for the labor they employ.

In the Civil Code, especially Article 1365, 1366, and 1367, this principle is firmly held. This principle states that a person can only be held accountable legally if there is an error element. Article 1365 of the Civil Code, which is known as an article about acts against the law, requires the fulfillment of four essential elements, namely: (1) 
the existence of action, (2) the presence of a fault, (3) the loss suffered and (4) the causal relationship between mistakes and losses. Regarding the distribution of the burden of proof, it follows Article 163 of Herziene Indonesische Reglement (HIR) or Article 283 of the Buitsengewesten Rechtsreglement (Rbg) and Article 1865 of the Civil Code. It is said that anyone who recognizes that he has a right must prove the existence of the right or event (actorie incumbit probatio).

The above provisions follow the general theory in procedural law, namely the principle of audi et alterm partem or the principle of equal standing between all parties who are litigants. Cases that need to be clarified in this principle are the subject of wrongdoers in Article 1367 of the Civil Code. Legal doctrine, known as the principle of vicarious liability and corporate liability.

Vicarious liability (also known as respondeat superior, let the answer) implies that the employer is responsible for losing other parties caused by the people/employees under his supervision. If the employee is loaned to another party, then the responsibility lies with the employee.

In principle, corporate liability has the same meaning as vicarious liability. The institution (corporation) that houses a group of workers has responsibility for the workers it employs. For example, in the legal relationship between a hospital and a patient, all responsibility for the work of medical personnel and paramedics is the burden of the hospital's responsibility where they work (Widjaja, 2020). This principle is applied to its organic employees (paid by the hospital) and to monorganic employees (for example, doctors contracted to work with profit-sharing). Suppose a corporation (such as a hospital) gives an impression to the community (patients). In that case, the people who work there (doctors, nurses, etc.) are subject to the corporation's command/coordination. The requirements for that corporation are sufficient must be responsible for its consumers.

1.Presumption is always responsible (presumption of liability)

The principle of responsibility states that a person is ever held responsible for his actions until the person can prove himself innocent;

2.Presumption is not always responsible (presumption of nonliability).

This principle is the opposite of the principle of presumption of always being responsible, where a person is considered irresponsible until it can be proven that he is guilty.

\section{b.Absolute responsibility (strict liability)}

This principle defines error not as a determining factor. Still,some exceptions make it possible for someone to be released from responsibility because ofcircumstances outside of a human will. In Indonesia, the concept of strict liability (absolute accountability, risk responsibility) can be implicitly found in Article 1367 and Article 1368 of the Civil Code. Article 1367 of the Civil Code regulates a person's liability for losses caused by goods under his supervision. For example, when the thing causes harm to others, for example, an owner of a particular item explodes and injures another person. The owner is responsible for the injuries inflicted, without questioning whether some mistakes or mistakes cause the explosion. Applying article 1367 of the Civil Code like this does require a bold enough interpretation, but it can already be used as one of its basics. The words under his supervision in article 1367 of the Civil Code can be seen as a stand-alone factor as the cause of the loss. It means there is no need for the fault of the owner of the goods.

Using the concept of strict liability in the bidag consumer protection, especially product responsibility, will facilitate proof, which protects consumers. It is not intended to place the producer 
in a difficult position solely. The producer's position is stronger than consumers. It is partly due to entrepreneurs' ability in the financial sector, the rapid advancement of industrial technology, and entrepreneurs' power to use the best legal experts in dealing with a case.

Another reason that can be used as a basis for applying or using the concept of strict liability in consumer protection, primarily product responsibility, is to look at the purpose of the protection itself. The word protection means that it makes it easy for consumers to maintain and/or obtain what they are entitled to.

\section{c.Limitation of liability}

Business actors usually prefer this principle to be included as a clause in the standard agreements they make. This principle is generally combined with other principles of responsibility. This limitation of liability principle is very much liked by business actors to be included as an exoneration clause in the standard agreement it makes. In a film print washing agreement, for example, it is determined, if the film that is to be washed or printed is lost or damaged (including due to an error of the officer), then the consumer has limited to compensation only ten times the price of a new roll of film.

\section{RESEARCH METHODOLOGY}

The research method used by the author is the normative legal research method. In normative legal research, answers to existing problems come from the literature. Some of the results and benefits of normative legal research are: (1) determining the relationship and legal status of the parties in a legal event; (2) provides a legal assessment (justification) of a legal circumstance. Is it wrong, right, or what should be according to law; and (3) aligning and maintaining the consistency of the system of norms against basic norms, principles, doctrines, contracts, and applicable laws and regulations. This research used secondary data, namely revealing the laws and regulations relating to the research object's legal theories, namely researching and analyzing criminal responsibility data processing companies processing data applications online transportation. To conclude, it useda descriptive-analytical approach.

\section{RESULT AND ANALYSIS}

The parties in online transportation include, among others: (1) Companies providing online transportation services; (2) Drivers; and (3) Users of online transportation services. An online transportation service provider company in the form of a legal entity provides transportation service provider applications. It is an Electronic System provider that provides technology-based applications in the field of land transportation. The relationship between the service provider company with the driver is divided into two aspects, namely: 1) material aspect, in the material aspect the driver acts as a partner of the service provider company based on agreements agreed upon by the parties electronically, giving rise to a legal partnership; and 2) formal aspects, the driver to provide transportation services using an application that is managed by a service provider company, then the driver indirectly acts as a consumer who uses the application to conduct his business activities.

In the material aspects of the partnership agreement that forms the basis of the legal relationship between the service provider and the driver, it must be made based on the parties' agreement and balanced. Each driver agrees to a partnership agreement between the partner and the service provider company by clicking the agreement electronically. So that each partner is declared to have agreed to be bound in a contractual cooperation relationship. Sincethe relationship is base on a partnership agreement, then what happens is not a working relationship 
with superiors and subordinates. There are messengers and recipients of orders because there is no work element, wages, or orders in this relationship.

In this partnership agreement, there is an element of equality between the parties. This equality occurs because there is no element of order and wages. The legal relationship between the application company providing online transportation services and the driver is equal, in the form of a partner. The legal relationship established is a partnership relationship that prioritizes benefits for the parties.

The partnership has the right to make a partnership agreement. Thus there must be a balance between the parties in the partnership agreement. Partnership agreements are inseparable from the rights and obligations of each party in the contract. In a partnership agreement, there must be an element of equality between the parties. Based on the partnership agreement in the application service provider company with the driver, there is an imbalance of rights and obligations between the application company and the driver. Most of what is stated in the partnership agreement, partners' obligations are more emphasized and more regulated, while regarding the rights of the driver's partners and the company's application obligations are not regulated much. Indirect driver obligations include the rights of the application company.

The service provider company has made the partnership agreement between the service provider company and the driver, so the driver only needs to agree to the entire contents of the contract without renegotiating its contents. A partnership agreement is a type of cooperation agreement that must be balanced and based on the parties' agreement and fulfill the contract's legal requirements as regulated in Article 1320 of the Civil Code. Contracts that have been agreed must still be implemented in good faith, taking into account the provisions of Article 1338 of the Civil Code.

The terms of this partner agreement are those determined by the application company. The driver must agree to what is in the partnership agreement if the driver wants to become a partner of the application company. There is the nature of the standard agreement and contains an exoneration clause, which is an agreement intended for drivers who involve themselves in this agreement. Exoneration clause is a condition that includes to free or limit a person's responsibility in agreeing.

The driver to run an online transportation business using the application makes a connection between the service provider company and the driver, indirectly causing the driver as a consumer of the application managed by the service provider company. Drivers in using the online transportation application are subject to the terms and conditions set by the service provider company. Indirectly the rights attached to the driver are protected by the Consumer Protection Act.

The legal relationship between service users and online transportation service providers occurs when the service user indirectly approves an agreement made by an online transportation service provider application company. The agreement is in the form of terms and conditions that must be agreed upon by the service user before the service user can use the application of the service provider company. The agreement arises and is agreed upon when the consumer downloads the application and creates an account containing the service user's data and states I agree to any conditions made by the online transportation service provider company to use the application. 
In organizing online transportation activities, the existence of a legal relationship between the service provider company with the driver and the legal relationship between the service provider company and the service user causes a legal relationship between the driver and the service user. The driver carries out the movement of people and/or goods from one place to another through transportation based on the service user's request in the application managed by the service provider company. The driver's obligation to transport is based on a partnership agreement made with an online transportation service provider company.

In the event of an illegal act committed by the driver as an online transportation service provider, then it must contain the following elements: the existence of an action; the act is against the law; there is an error on the part of the perpetrator; any loss for the victim; and the causal relationship between actions and losses.If the driver is acting unlawfully, the driver is fully responsible for the act as an online transportation service provider. So the driver as an online transportation service provider in the event of committing an act against the law can be sued for compensation. The concept of compensation in law is known in two law areas. The first concept of compensation is due to breach of contract. The second concept of compensation due to an agreement based on the law. It includes compensation due to acts against the law.

The legal relationship created between service users and service providers, in this case, the driver, is the relationship between consumers and businesses. Then the driver has the responsibility in terms of the consumer protection law. The business actor must be responsible for compensating consumers in the case caused by the business actor, including: a. Business actors are responsible for providing compensation for damage, pollution, and/or consumer losses due to consuming the goods and/or services produced or traded;

b. The compensation can be in the form of refunds or replacement of goods and/or services of the same type or other equivalents, or health care and/or compensation under the provisions of the prevailing laws and regulations;

c. The compensation is given within 7 (seven) days after the transaction;

d. The granting of compensation does not eliminate the possibility of criminal prosecution based on further evidence regarding the existence of an element of error;

e. The provisions referred to in points $a$ and $b$ above do not apply if the business actor can prove that the error is the customer's fault.

In the event of an illegal act committed by the driver as an online transportation service provider, then it must contain the following elements: the existence of an action; the act is against the law; there is an error on the part of the perpetrator; any loss for the victim; and the causal relationship between actions and losses.

For these illegal acts committed by online transportation service providers, in this case, the drivers include, among others: nominal compensation; and punitive damages. Suppose there is a serious unlawful act, such as an act which contains an element of intent but does not cause a real loss to the victim. In that case, the victim can be given a certain amount of money in nominal compensation under a sense of justice without calculating the actual loss.

In organizing online transportation, the driver, the company providing online transportation services, and service users are interrelated and cannot be separated. Even though they are not a transportation company, online transportation 
service provider application companies are still business actors based on business actors in the Consumer Protection Law.Regarding the responsibility of these business actors, it is regulated in Article 19 of the Consumer Protection Law, which states that business actors must be responsible for compensating consumers for losses caused by business actors, including:

a. Business actors are responsible for providing compensation for damage, pollution,and/or consumer losses due to consuming goods and/or services produced or traded;

b. The compensation can be in the form of refunds or replacement of goods and/or services of the same type or other equivalents, or health care and/or compensation following the provisions of the prevailing laws and regulations;

c. The compensation is given within 7 (seven) days after the transaction;

d. The granting of compensation does not eliminate the possibility of criminal prosecution based on further evidence regarding the existence of an element of error;

e. The provisions referred to in points $a$ and $b$ do not apply if the business actor can prove that the error is the customer's fault.

The responsibilities of business actors include liability for compensation for damage, pollution, and loss to consumers. Responsibilities related to advertising, making advertising according to Consumer Protection Law must be done correctly and not misleading. One of which is regulated in article 10 of the Consumer Protection Law,which states that businesses in offering goods and/or services intended for trading are prohibited from offering, promoting, advertising or making false or misleading statements regarding prices or tariffs of goods and/or services. The use of an item and/or service; conditions, dependents, guarantees, rights or compensation for goods and/or services; discounted offers or attractive prizes offered; danger of using goods and/or services.

Online transportation service provider companies must make rules regarding sanctions for their partners, namely the driver as an online transportation service provider. Thus, the online transportation service provider company is also responsible for always supervising its work partners and cannot mention that its partners are independent parties independent of the online transportation service provider application company. It is because there will not be created a service provider if there is no application company.

Some requirements must be met in making a party as a partner for the online transportation service provider application company. With the provisions that must be completed and the existence of rules that bind the partner to the application company, the application company can always be responsible for these partners. If an event occurs, it cannot be said that the application company is free of responsibility, even if the agreement between them is stated as such.

An online transportation service provider application company is the party responsible for selecting partners with the rules that must be fulfilled by their partners. Thus the online transportation service provider application company has responsibility for its partners. Therefore in the event of an illegal act by the driver as a provider of online transportation services to service users, the application company must also be held responsible. Because according to the applicable provisions, the application company, as one of the business actors that provide services, must protect service users, including safety, security, and comfort. The application company is also obliged to ensure that the driver as his partner is always the same person. Following the driver's identification as a 
partner registered with the application company and to become a partner, in this case, the driver must meet the requirements. There is a code of ethics that must always be adhered to when becoming a partner.

The liabilities that can be requested by service users as consumers in the event of adverse action against the law is to submit a claim for compensation, a form of compensation for an unlawful act is known by law, namely: nominal compensation; punitive damages.

\section{IMPLICATION AND RECOMMENDATION}

The analysis recommends that the Republic of Indonesia's governmentamend Article 1 number (3) in the Consumer Protection Act. It must be read as follows.

"Business Actor is every individual or business entity, whether in the form of a legal entity legal or non-legal entity established and domiciled or carrying out activities within the jurisdiction of the Republic of Indonesia, both alone and with third parties through agreements to carry out business activities directly or indirectly find out information, receive profits, ensure and monitor the implementation of business activities ondemand consumers in various fields of economics."

The author also proposes to service provider companies that manage information technologybased applications in transportation to take responsibility for the problems that occur between consumers and drivers. It is part of the service provider's duty. It shall include the limitations of the responsibility of service provider companies that manage these applications in good agreement. with consumers and with drivers as partners. But also monitor and maintain the behavior of each partner so as not to act against the law. And remain responsible for any events that occur in organizing online transportation for using the application provided by them. Service provider companies that manage information technologybased applications in transportation are business actors. Consumers of service users who use applications are consumers of drivers as transport service providers and consumers of application companies using these applications. Therefore legal provisions for protecting consumers are binding for service provider companies as application managers.

\section{REFERENCES}

[1] Asshiddiqie, Jimly, and Ali Safa'at. (2006). Hans Kelsen Theory on Law. Jakarta: Konstitusi Press.

[2] Hamzah, Andi. (2005). Law Dictionary. Jakarta: Ghalia Indonesia.

[3] Kelsen, Hans Kelsen. (2006). General Theory on Law and State (translation). Jakarta: PT. Raja Grafindo Persada.

[4] Kristiyanti, Celina Tri Siwi. (2009). Consumer Protection Law. Jakarta: Sinar Grafika.

[5] Muhammad, Abdulkadir. (2020). Indonesia Compnay Law. Jakarta: Citra Aditya Bakti.

[6] Mustafa, Bachsan. (2016). Comprehensive ndonesian Legal System. Bandung: PT. Citra Aditya Bakti.

[7] Rahardjo, Satjipto. (2014). Jurisprudence. Bandung: Citra Aditya Bakti.

[8] Triwulan, Titik, and Shinta Febrian (2010). Legal Protection for Patients. Jakarta: Prestasi Pustaka.

[9] Widjaja, Gunawan. (2017)a. "The Importance of Comprehensive Trusts Law in Indonesia." International Journal of Applied Business and Economic Research. 2017:15(19);149-155.

[10] Widjaja, Gunawan. (2017)b."Implementation of Public-Private Partnership in Indonesia." International 
Journal of Economic Research. 2017;14(15):235-245.

[11] Widjaja, Gunawan. (2020). Good Hospital Governance In Indonesia And The Role Of Pharmacists. European Journal of Molecular \& Clinical Medicine, 7(3), 1450-1455. 